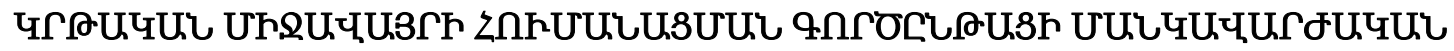 TU3UUนしER
}

คกФกЋ.23Uน U. O.

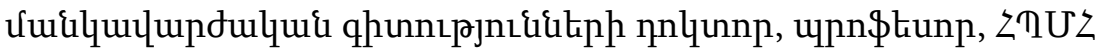

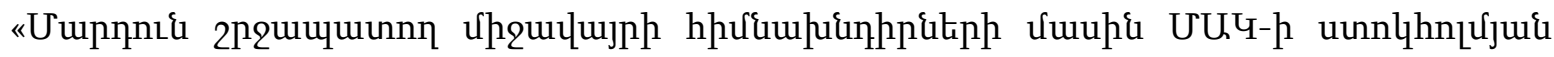

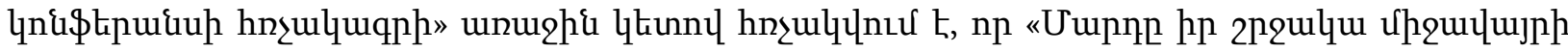

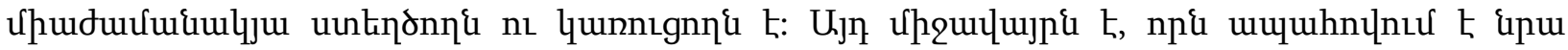

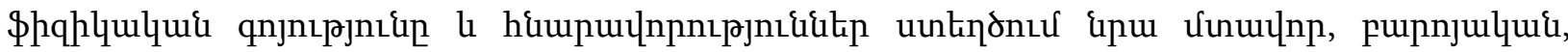

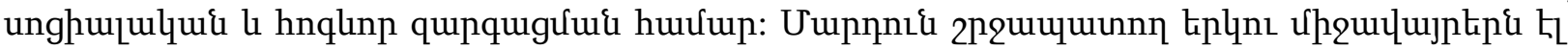

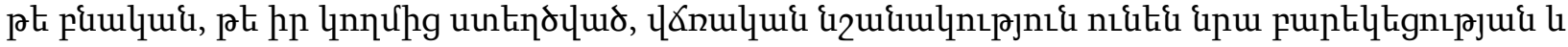

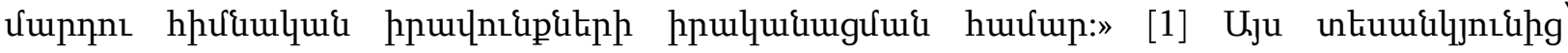

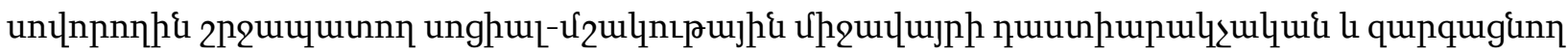

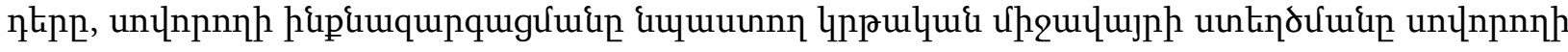

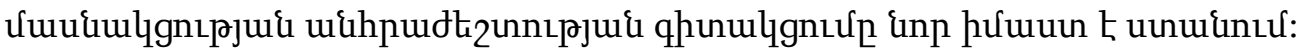

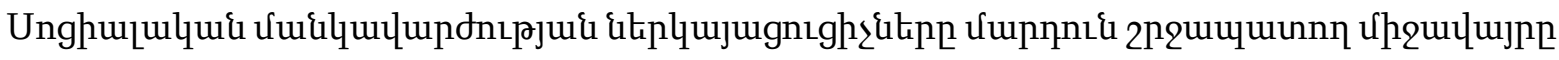

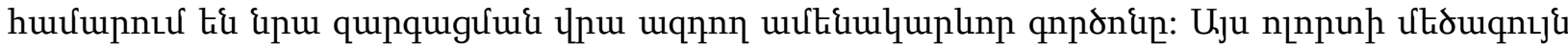

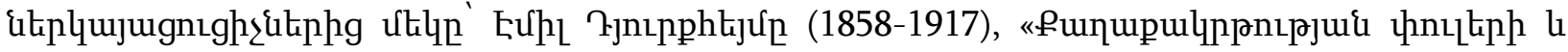

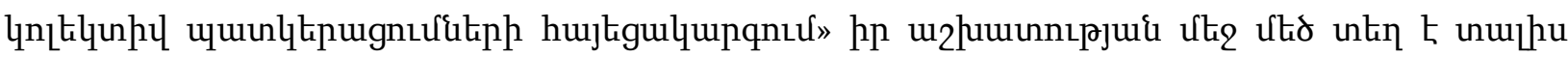

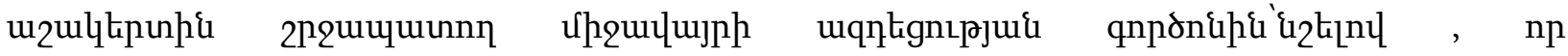

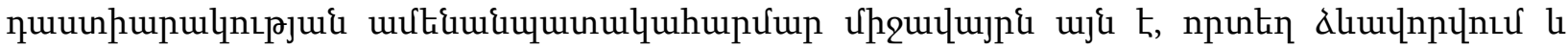

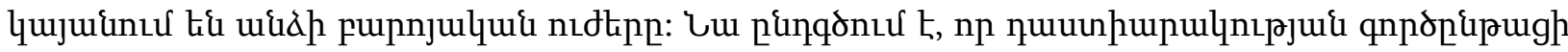

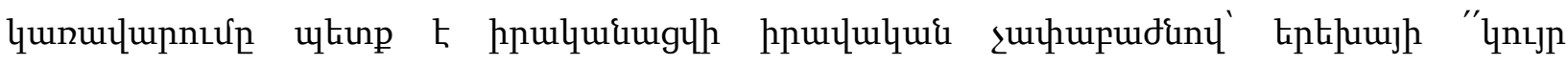
hiuuquinnıpjuik" puigunưuuf: [2, 225]

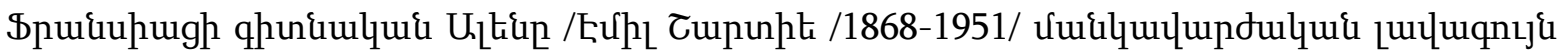

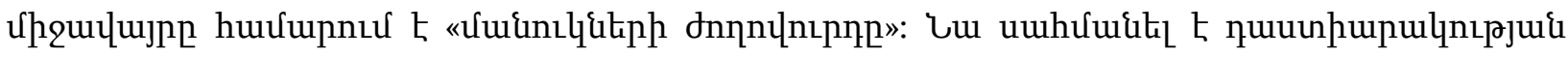

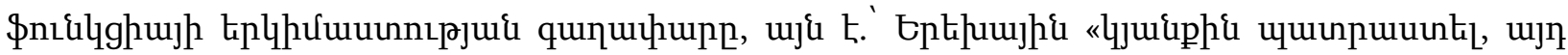

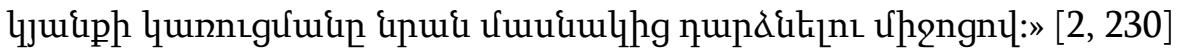

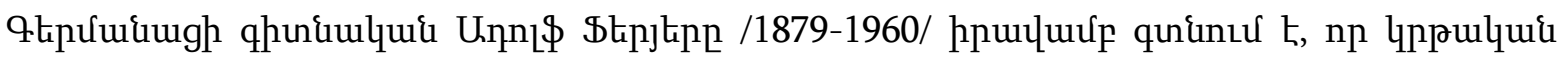

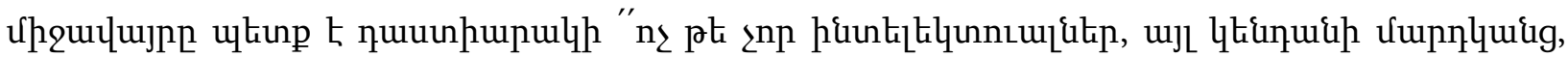

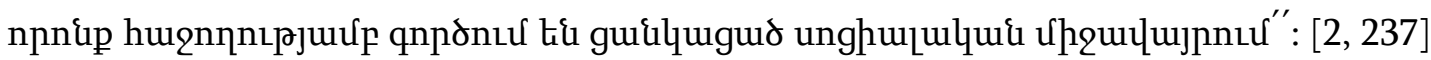

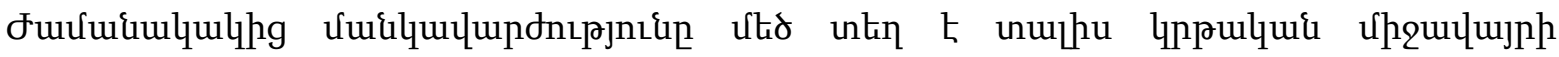

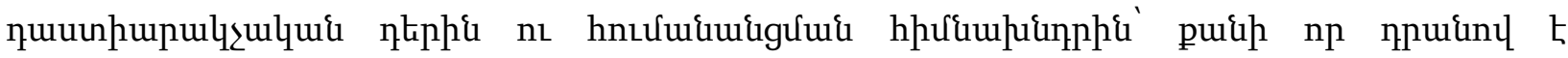




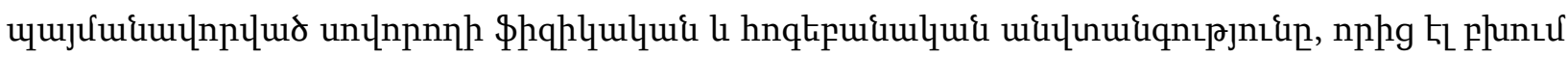

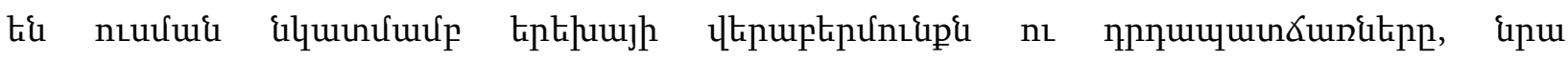

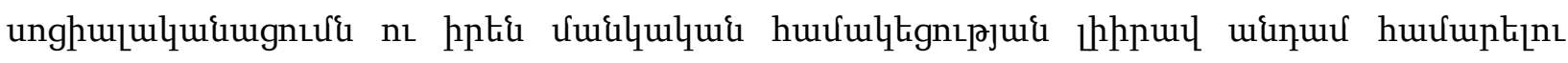
qquignıu:

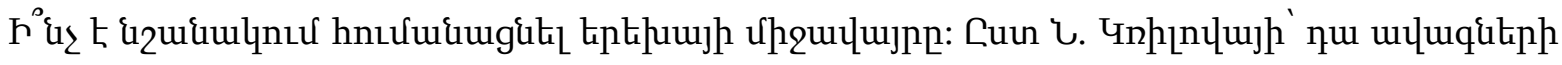

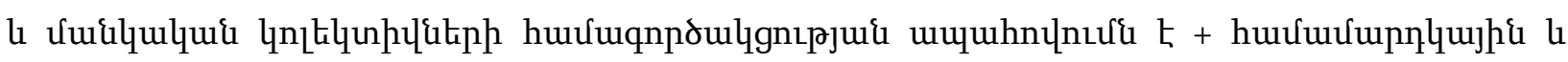

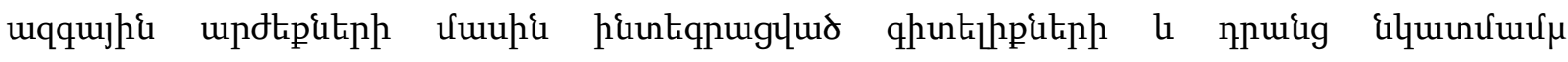

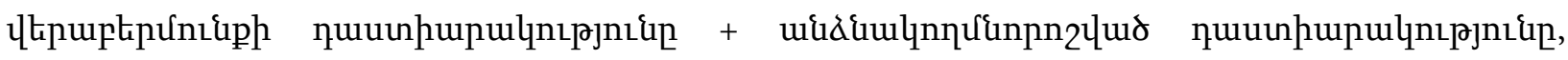

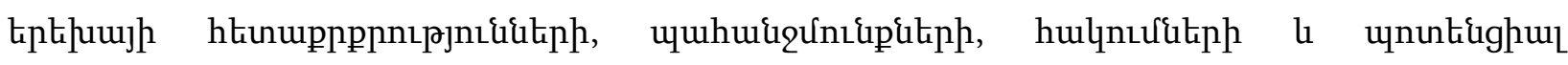

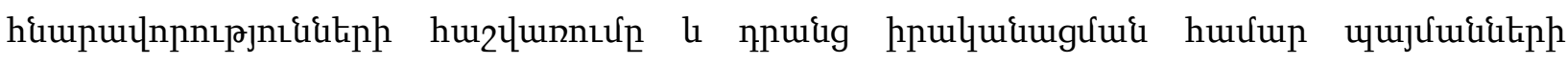
uutindnuर्ua k: [3 kq 219]:

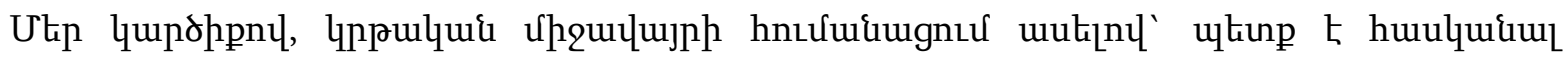

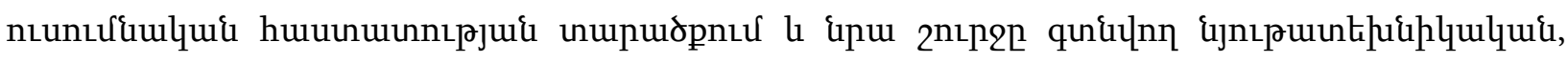

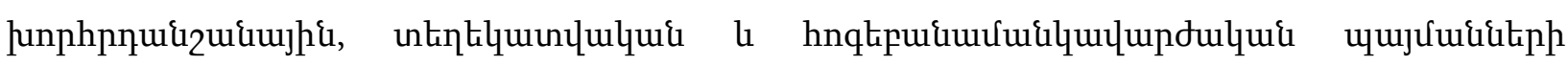

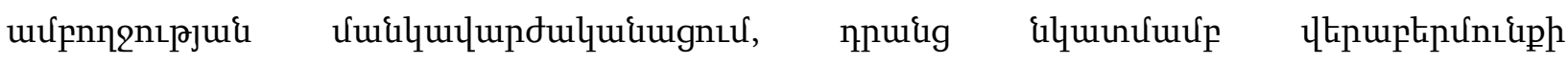

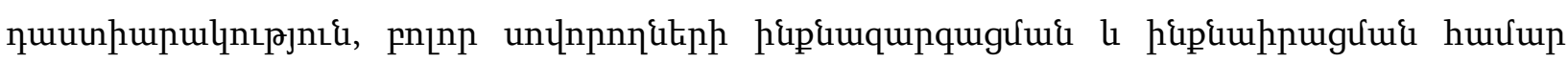

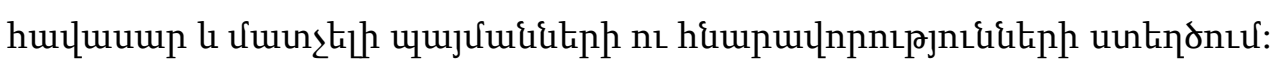

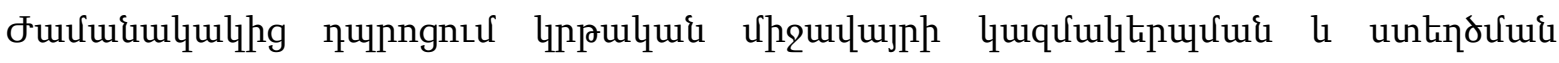

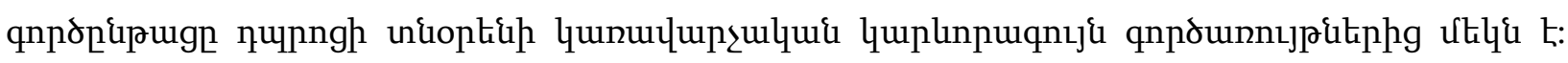

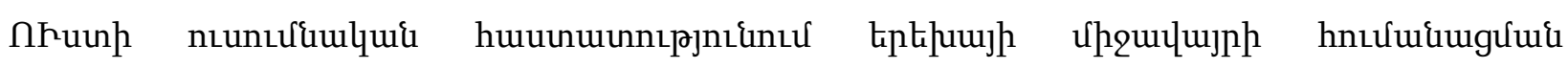

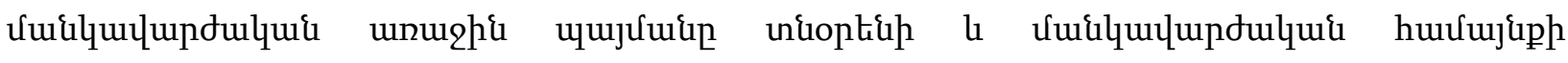

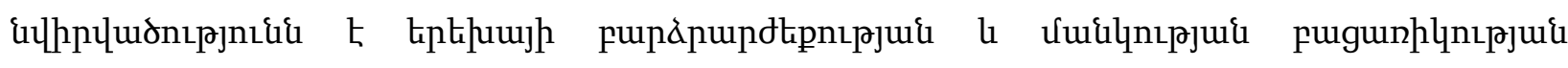

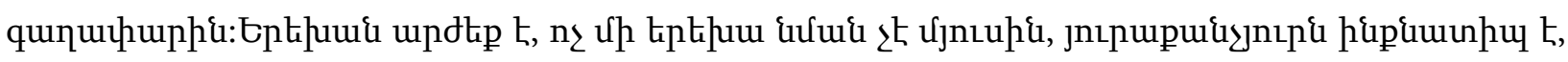

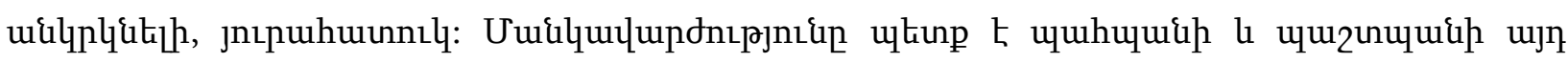

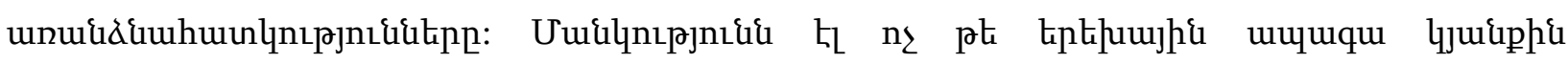

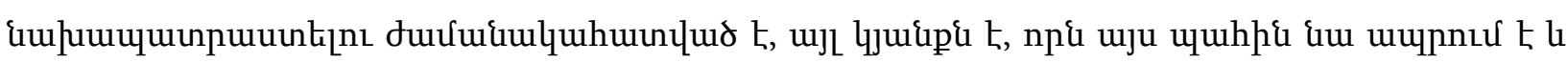

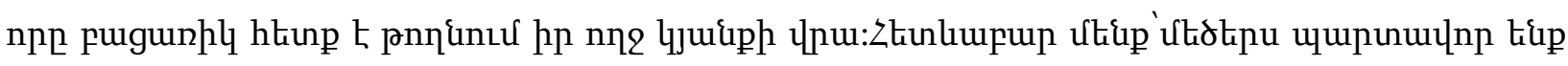

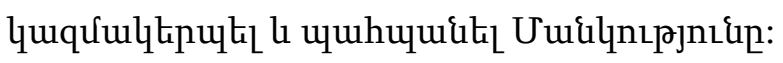

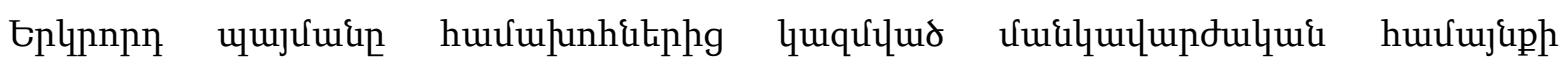

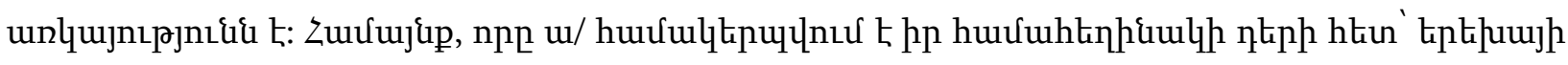

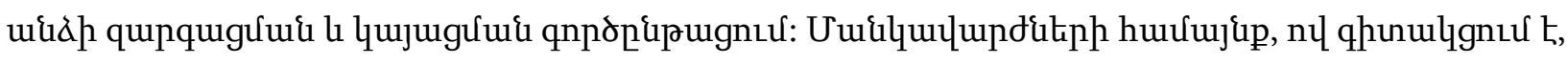

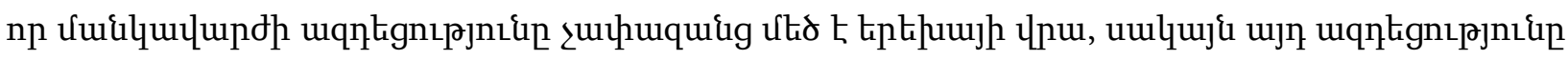

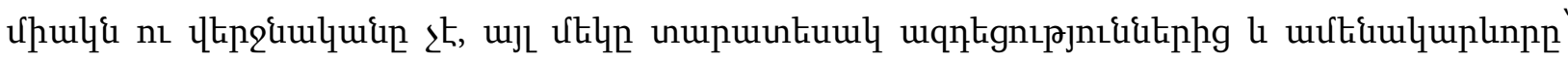




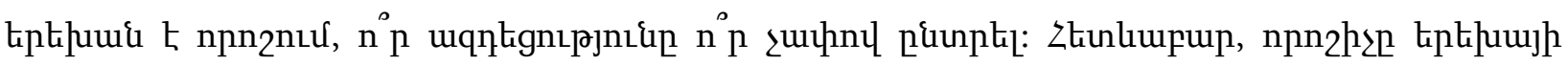

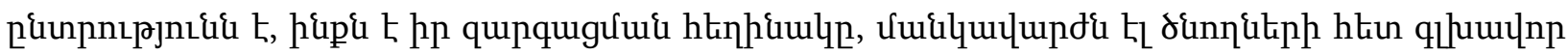

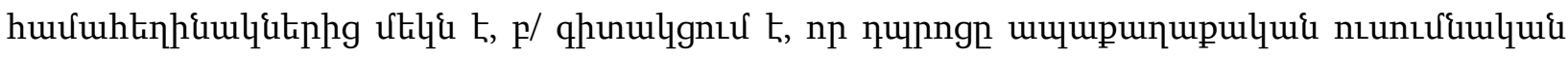

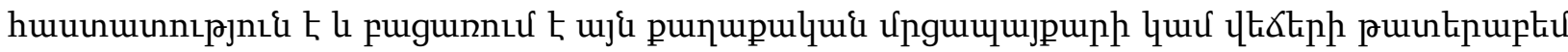

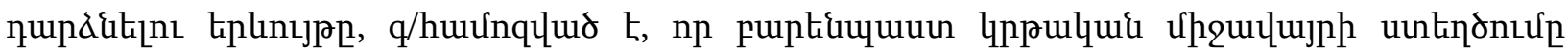

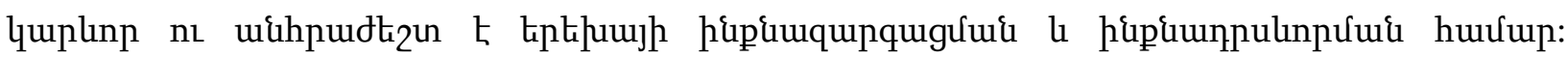

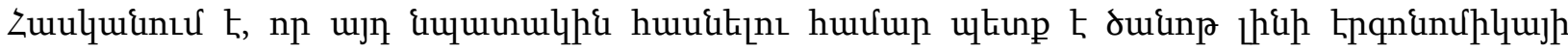

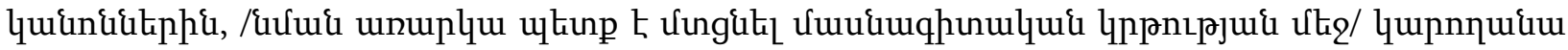

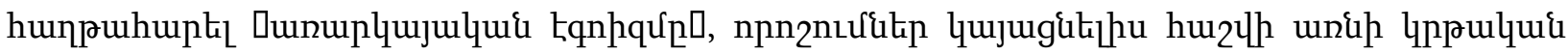

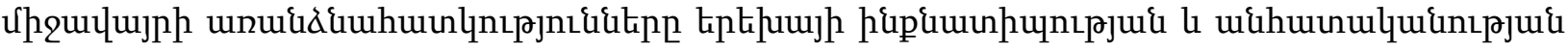

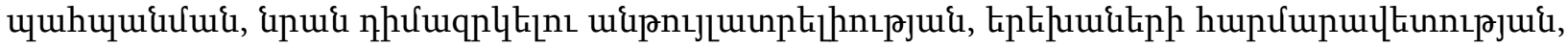

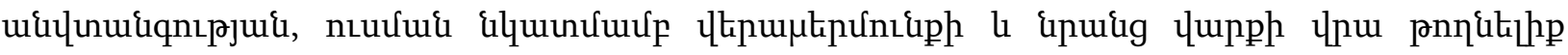

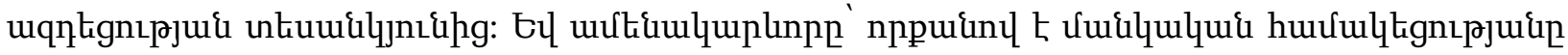

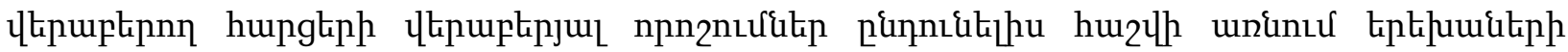

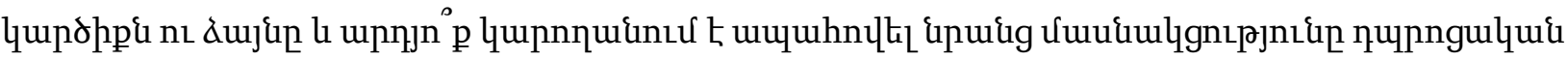

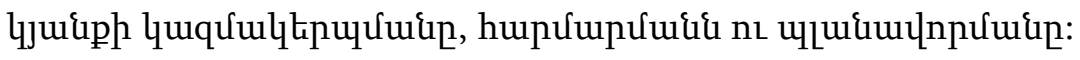

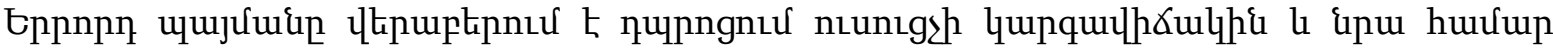

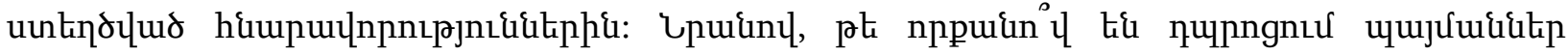

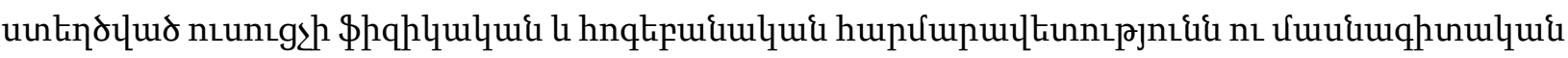

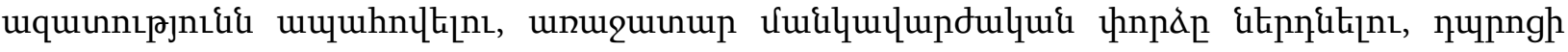

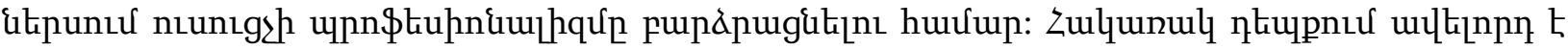

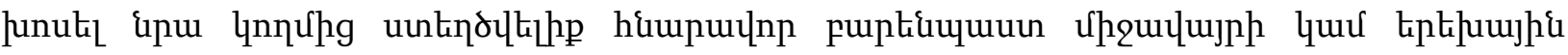

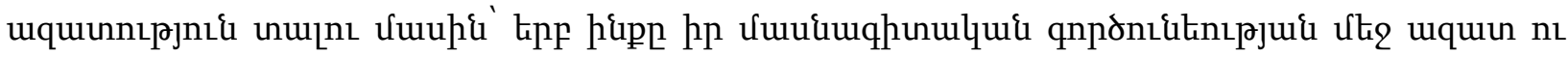

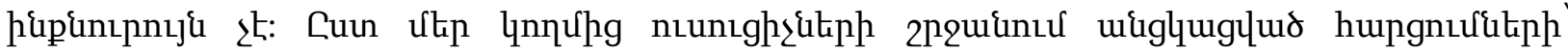

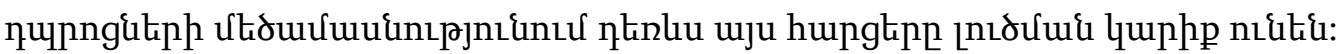

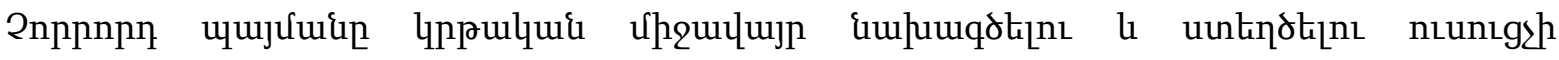

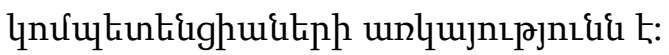

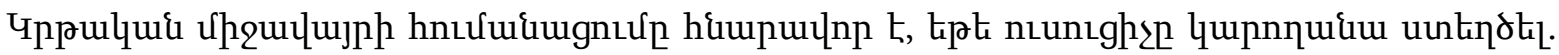

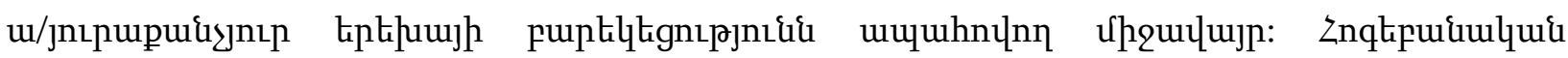

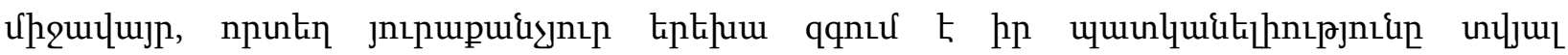

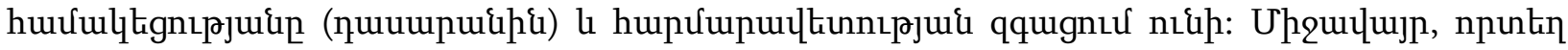

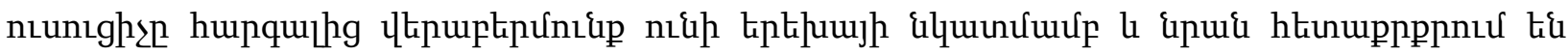

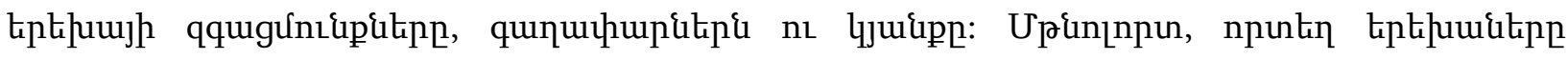




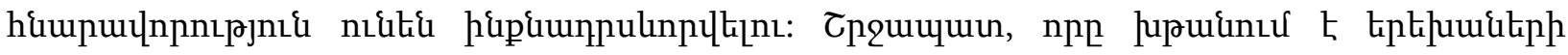

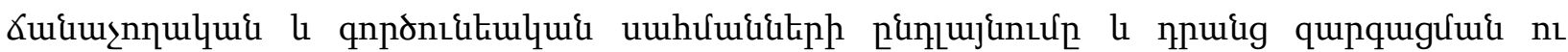

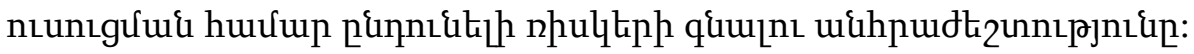

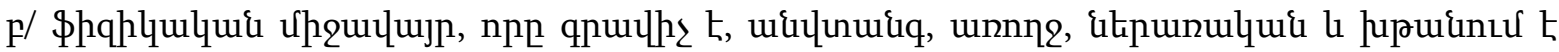

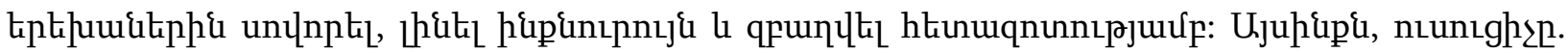

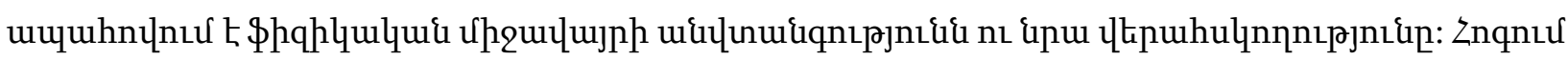

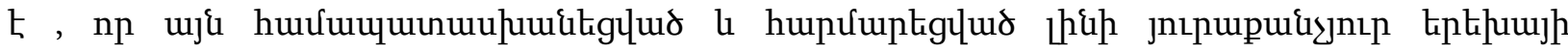

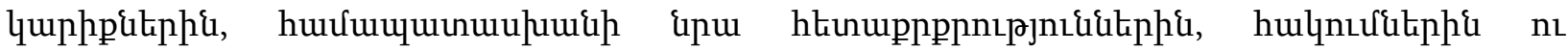

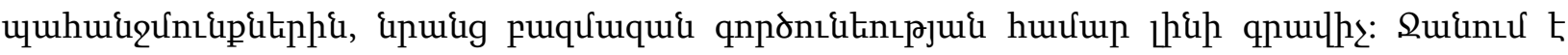

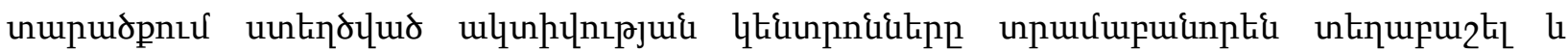

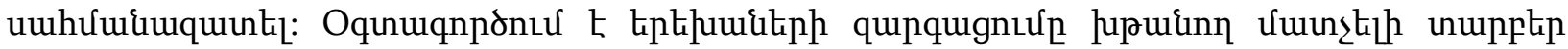

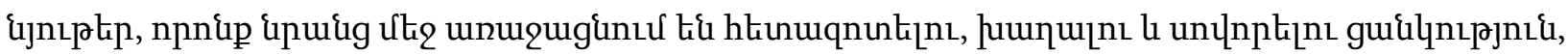

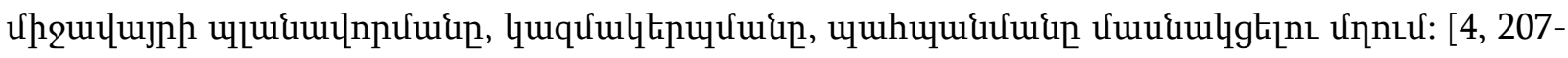
216]

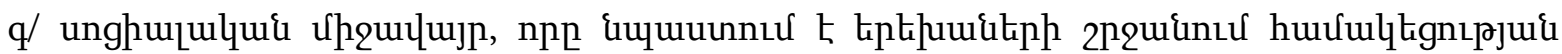

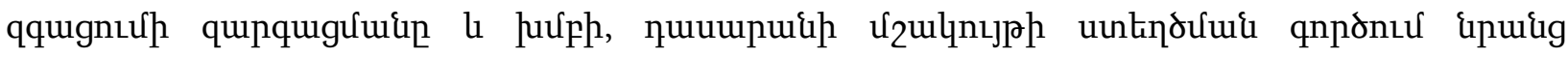

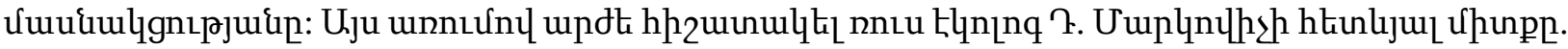

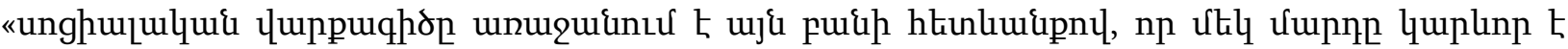

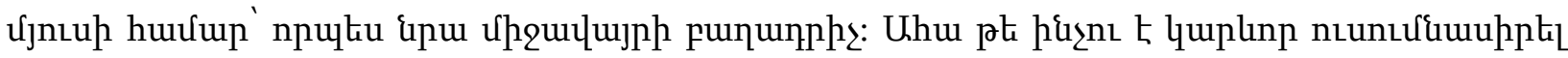

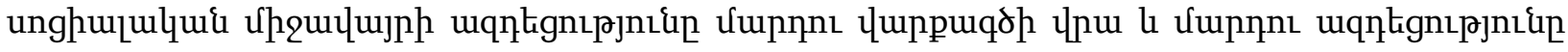

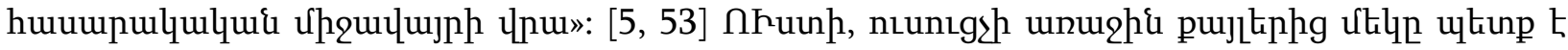

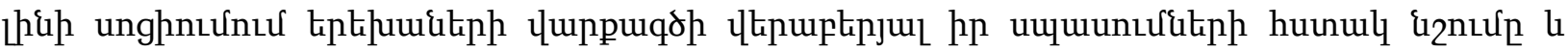

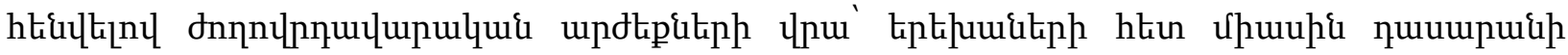

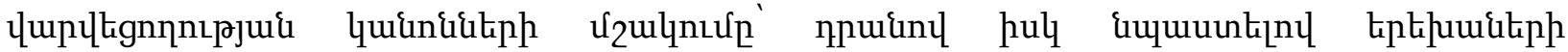

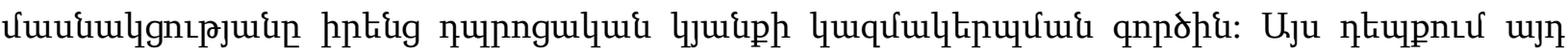

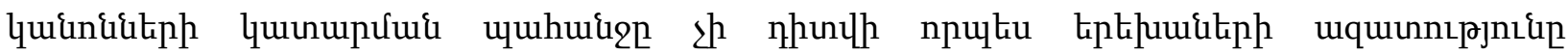

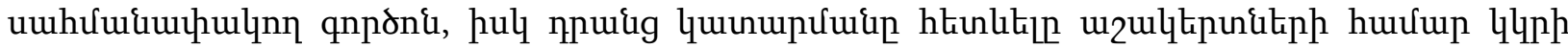

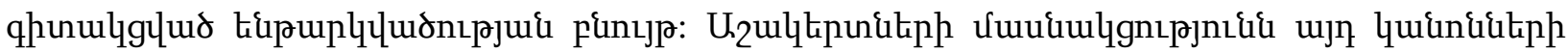

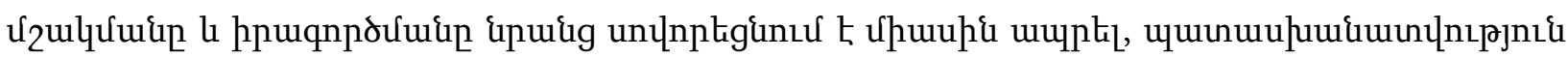

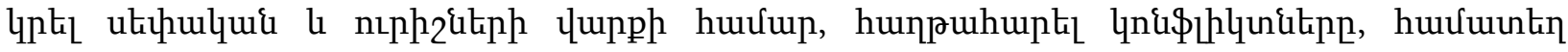

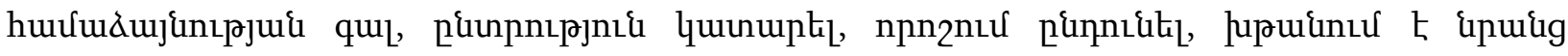

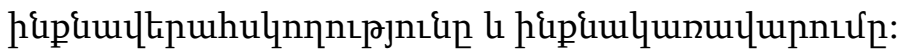

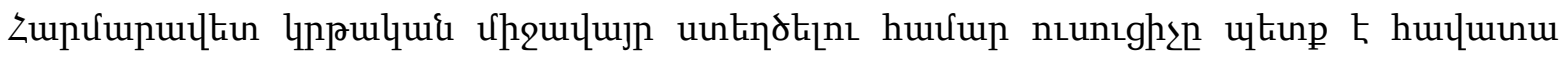




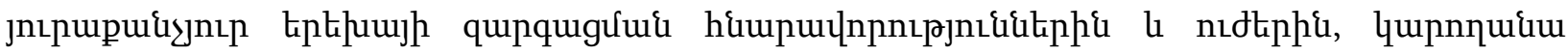

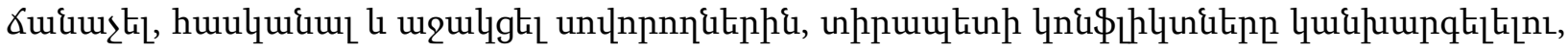

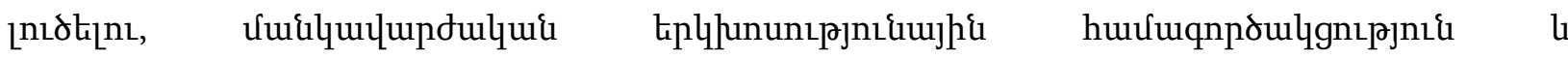

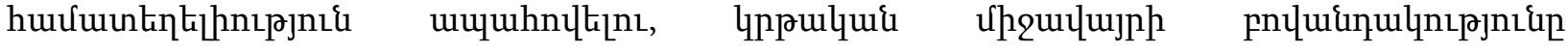

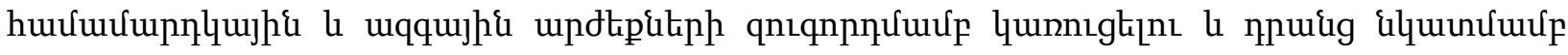

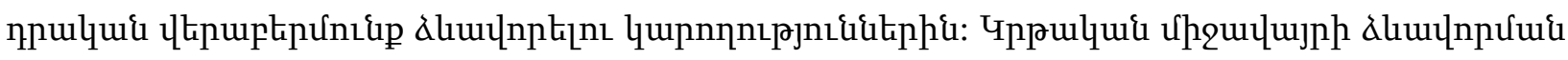

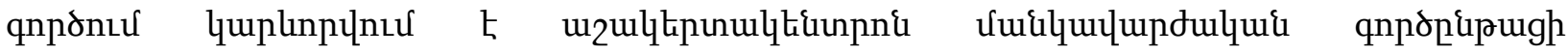

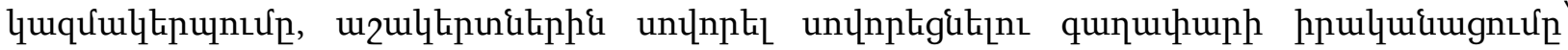

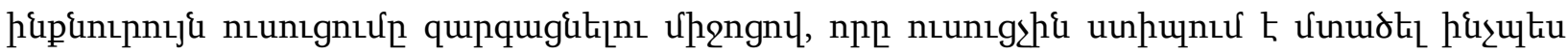

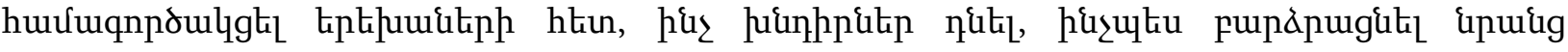

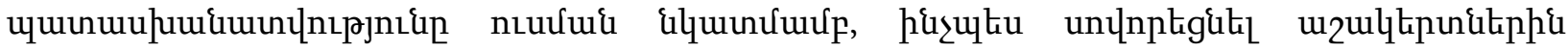

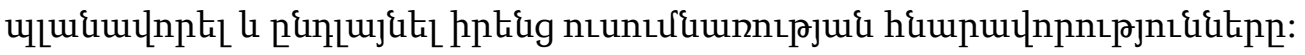

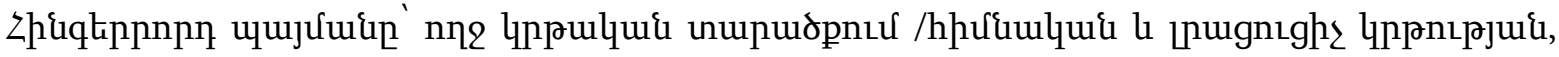

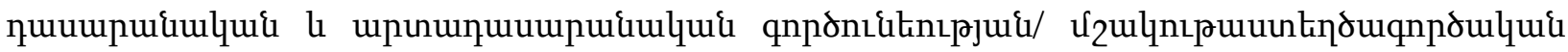

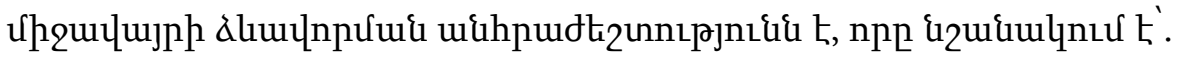

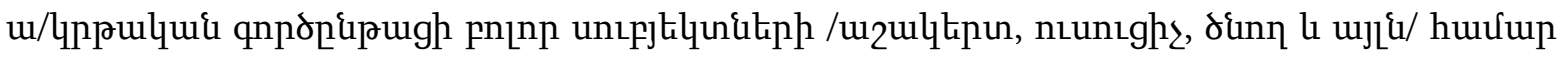

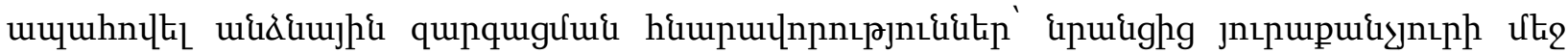

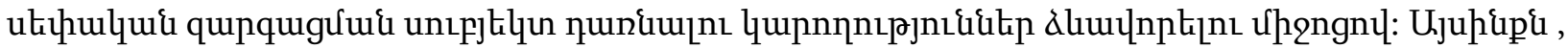

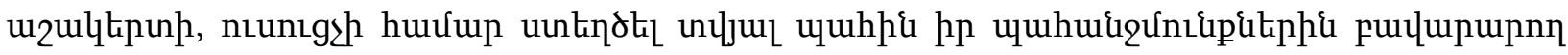

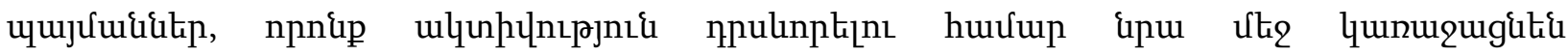

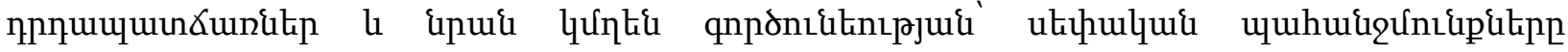

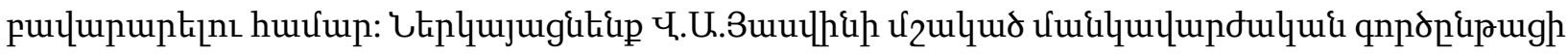

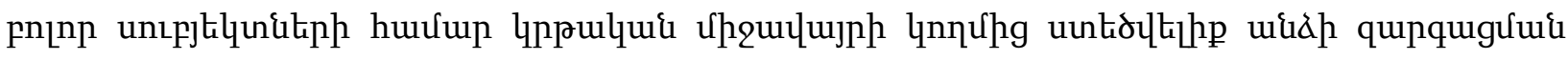

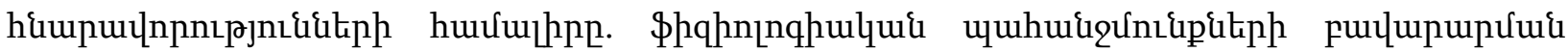

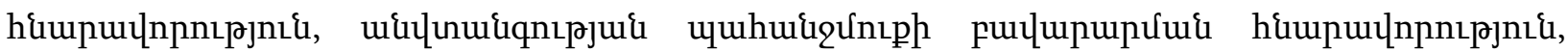

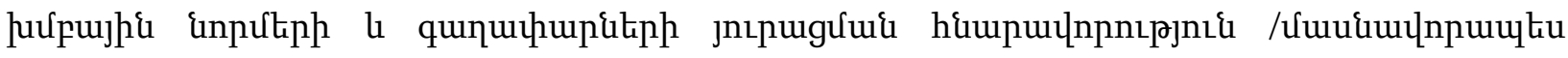

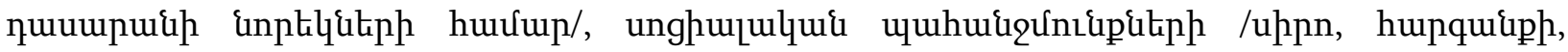

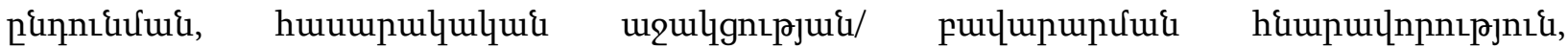

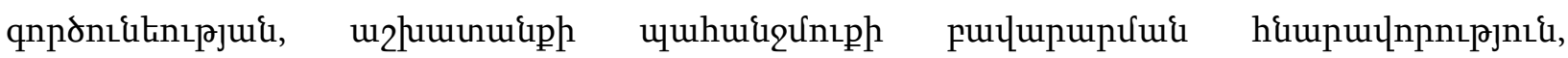

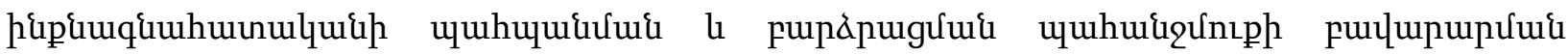

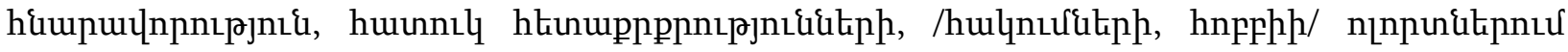

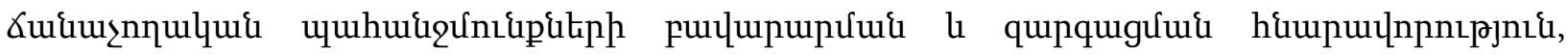

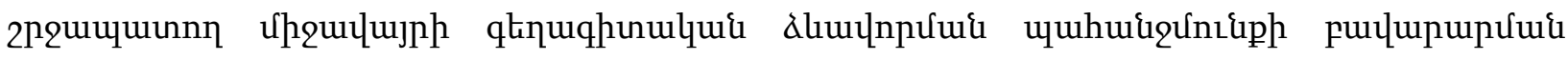




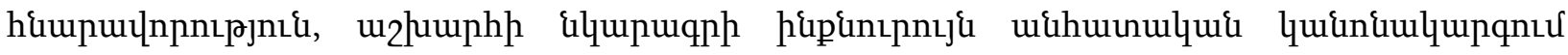

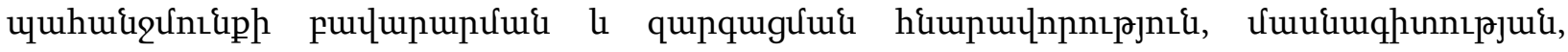

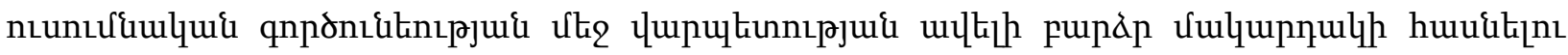

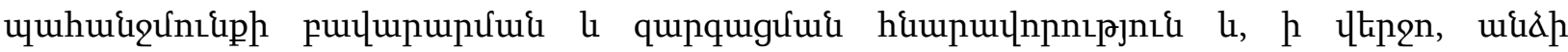

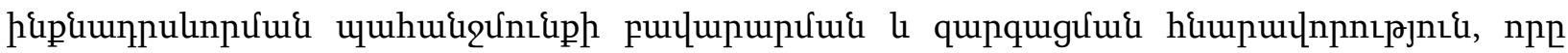

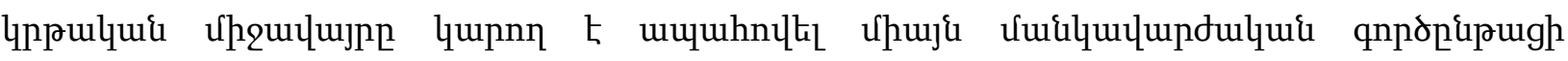

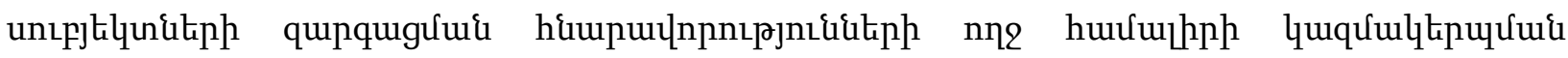

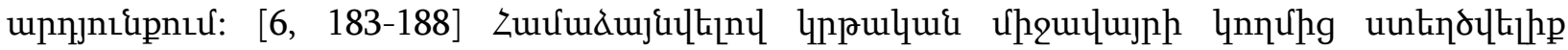

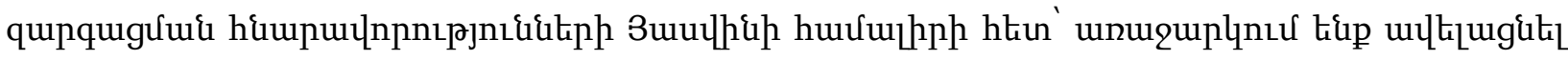

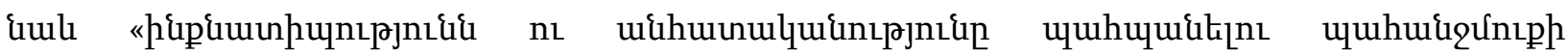

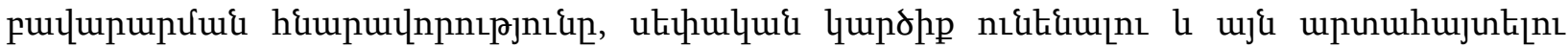

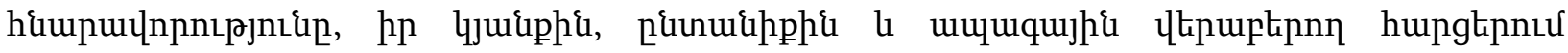

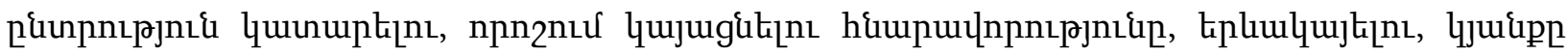

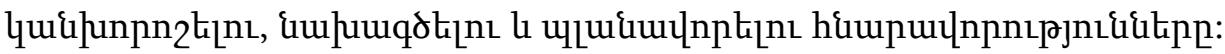

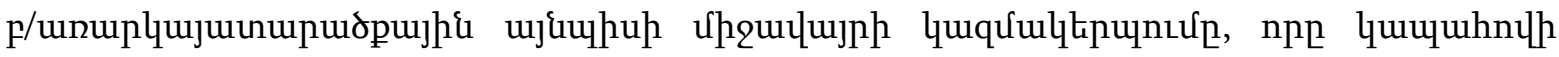

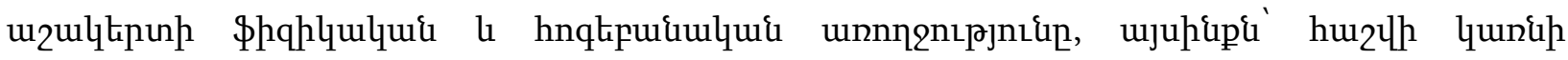

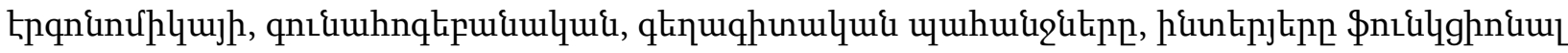

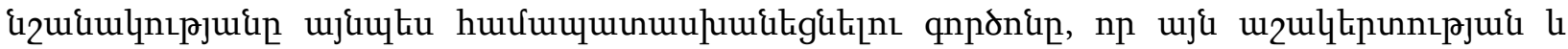

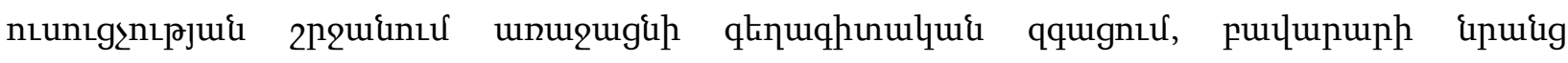

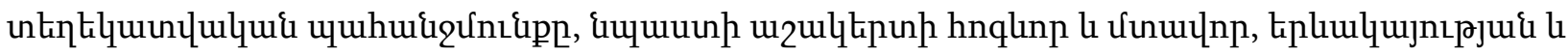

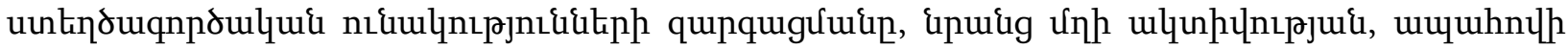

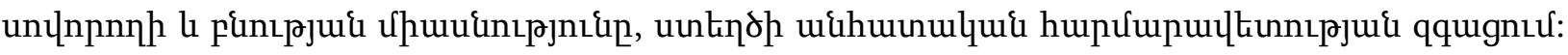

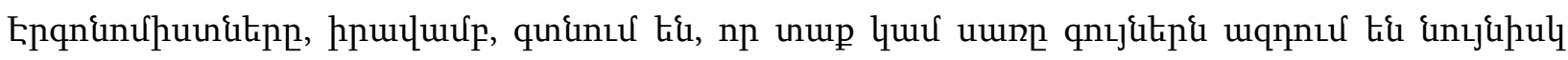

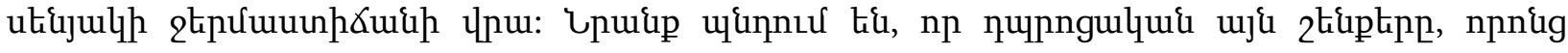

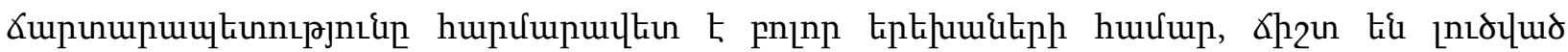

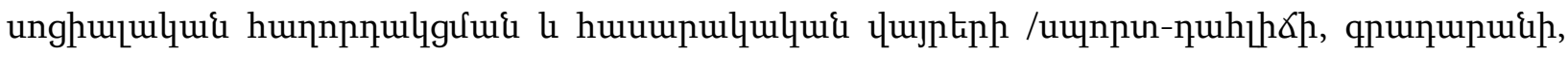

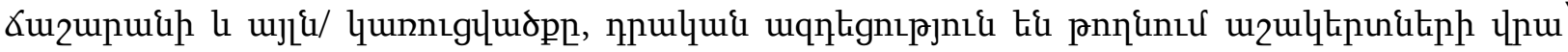

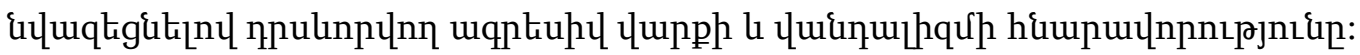

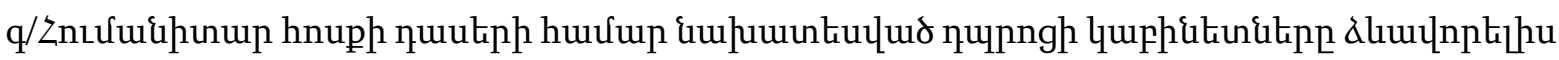

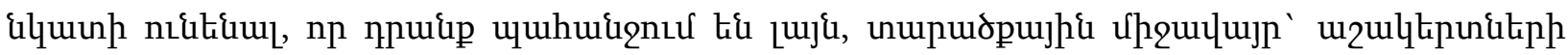

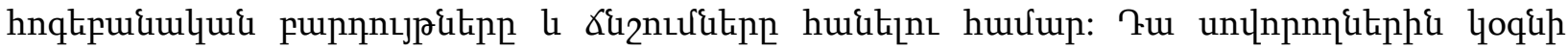

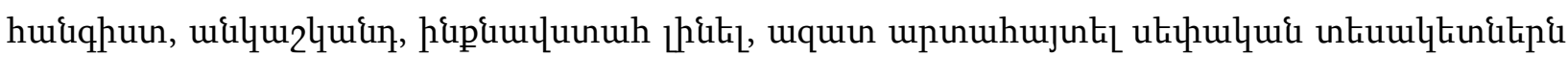
nı lunßhpitinn: 


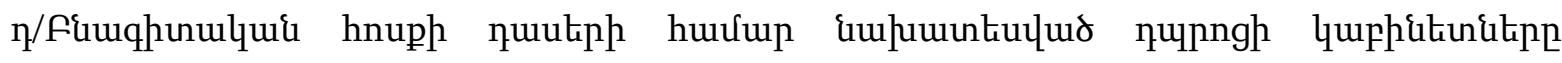

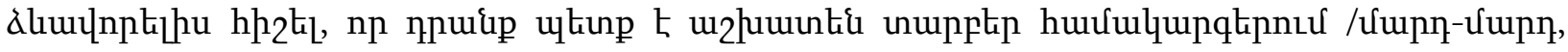

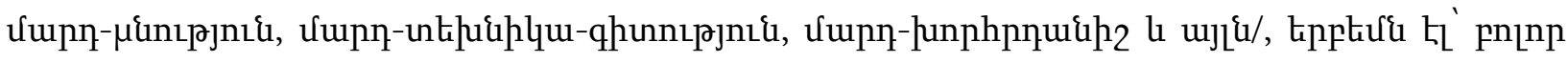

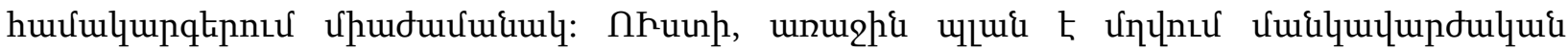

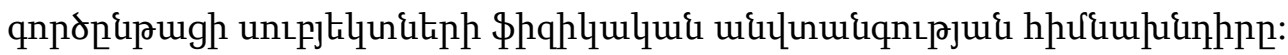

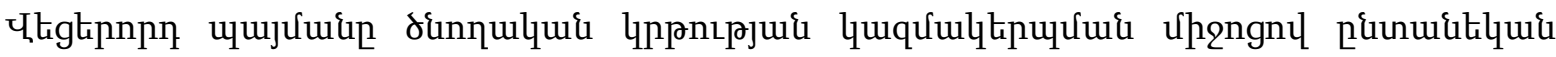

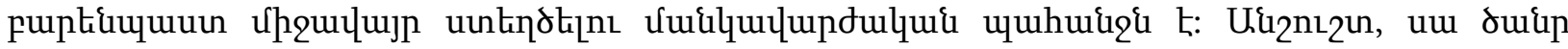

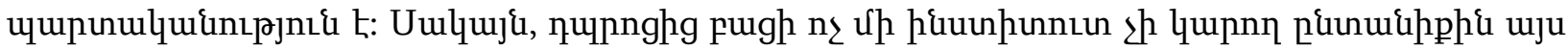

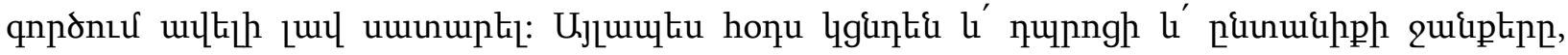

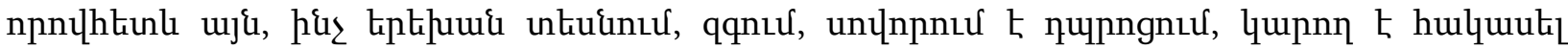

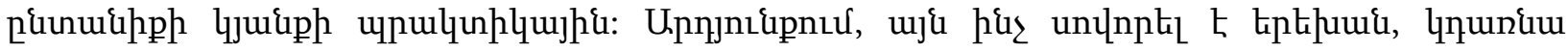

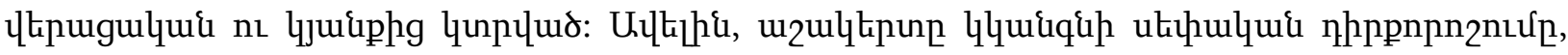

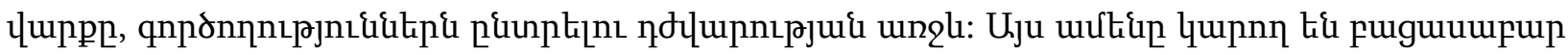

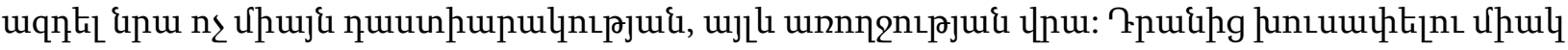

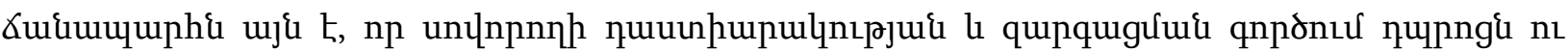

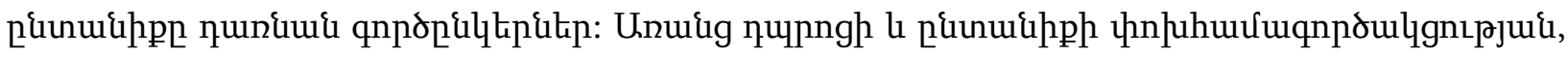

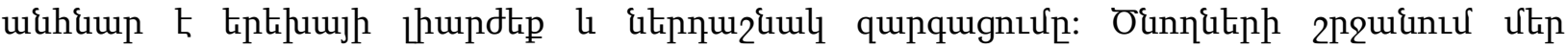

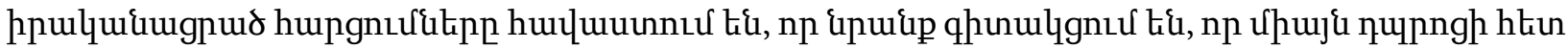

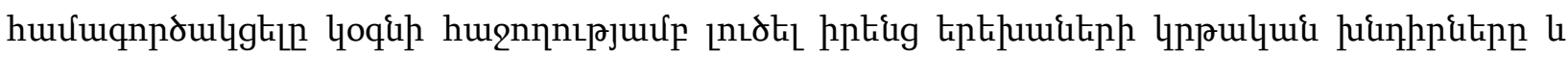

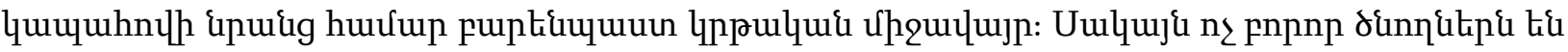

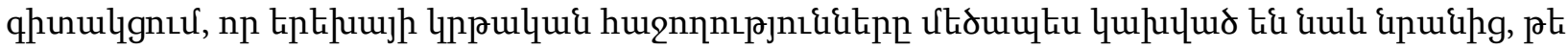

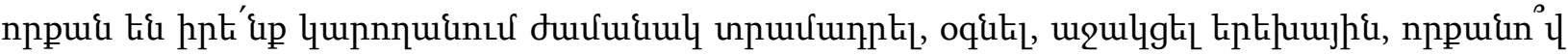

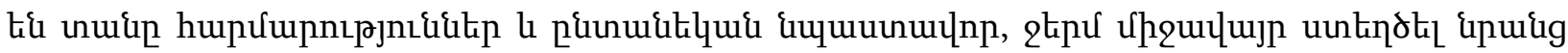

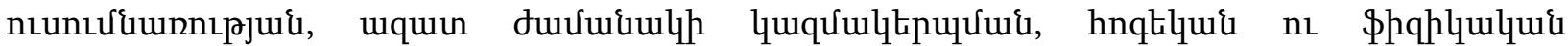

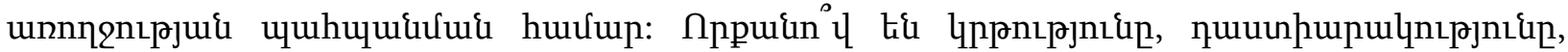

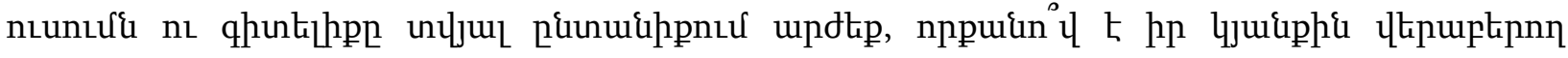

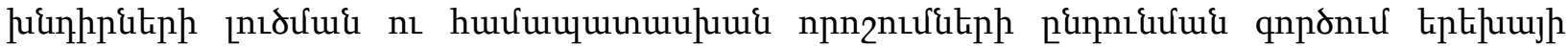

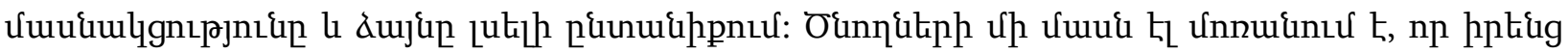

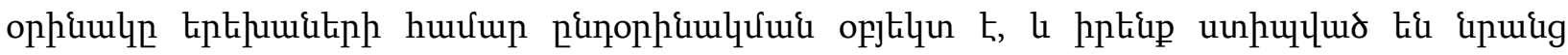

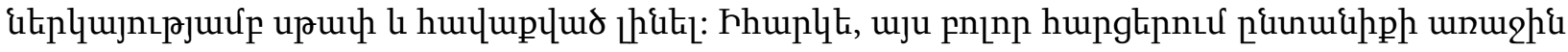

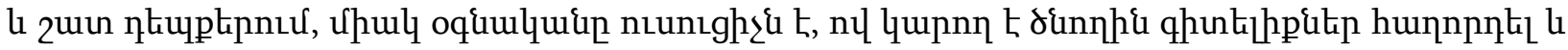

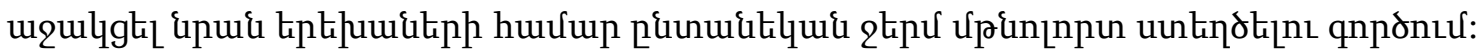

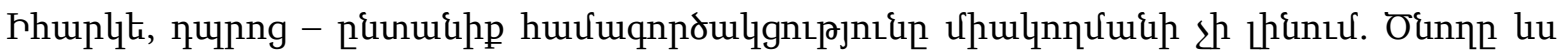




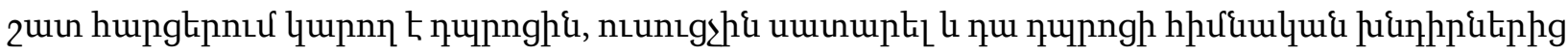

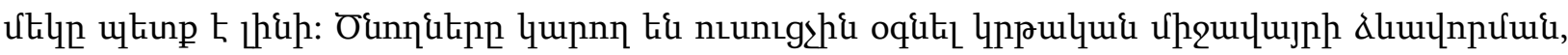

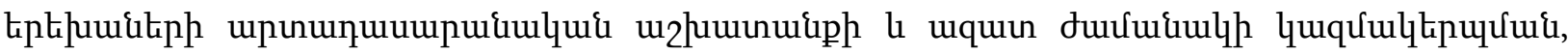

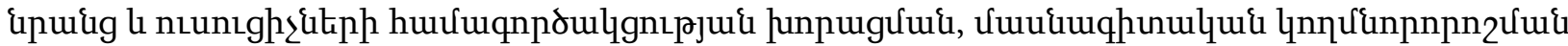
lu ujl hungtinnıu:

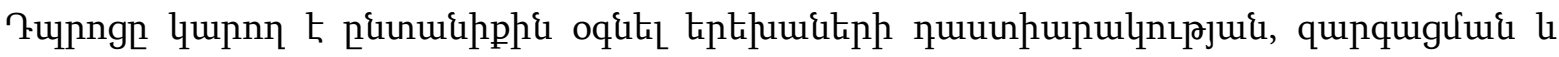

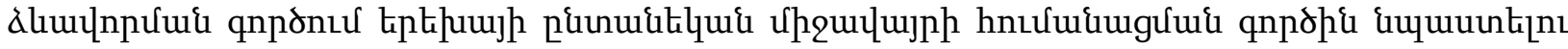
uhengnu: Tur tipumpnud t.

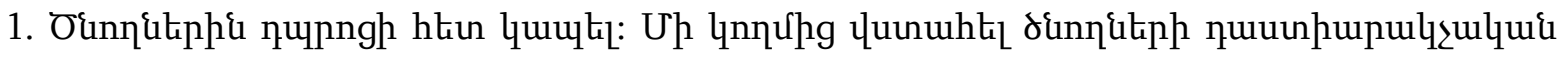

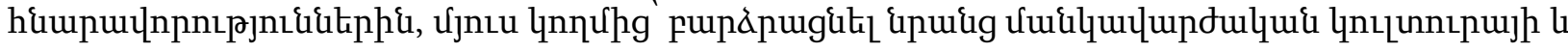

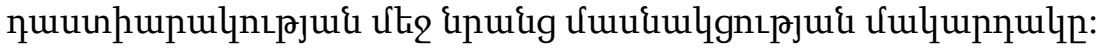

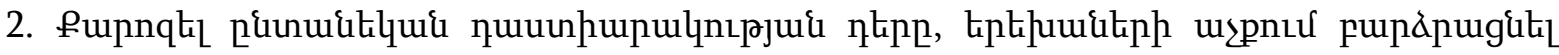

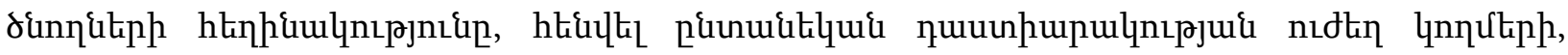

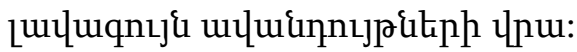

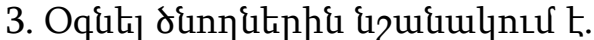

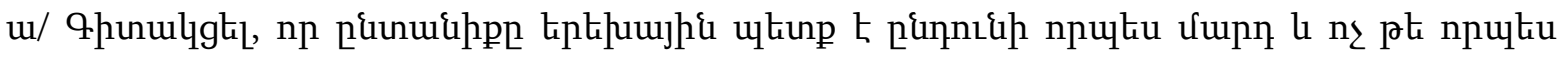

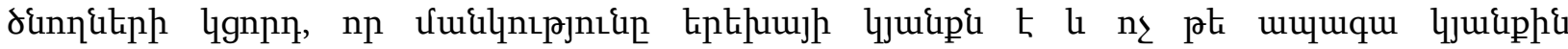

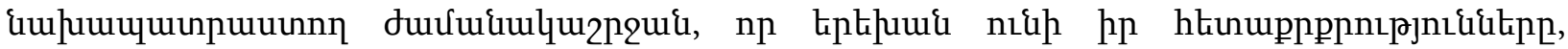

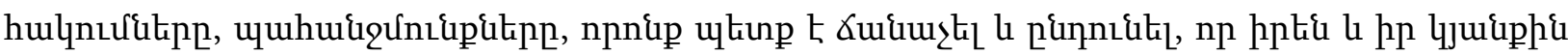

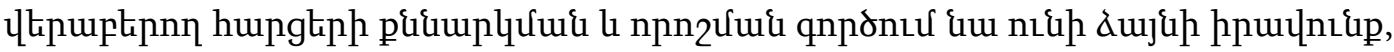

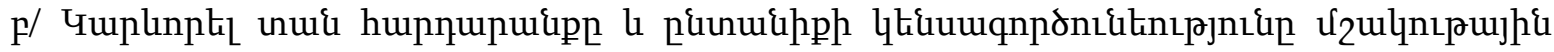

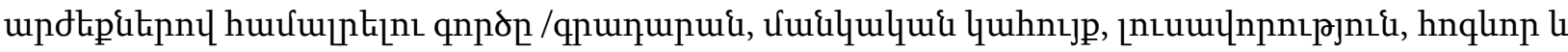

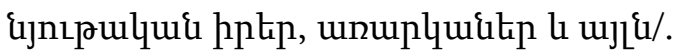

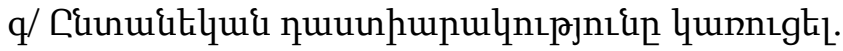

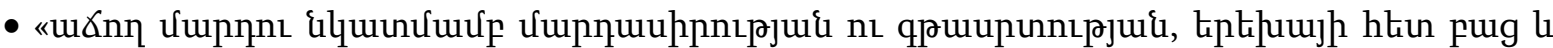

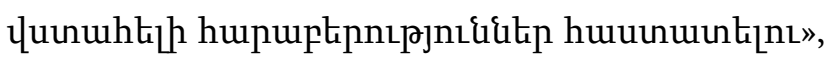

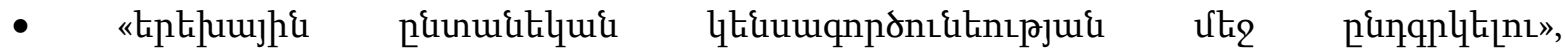

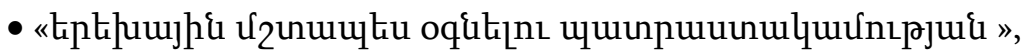

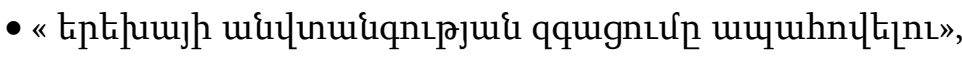

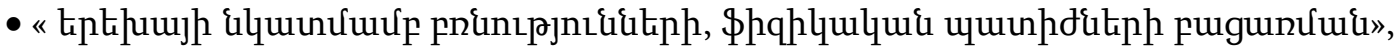

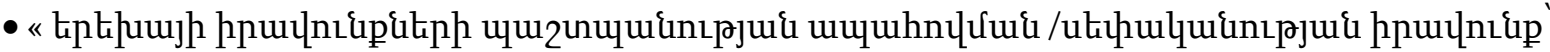

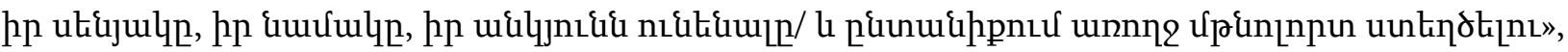

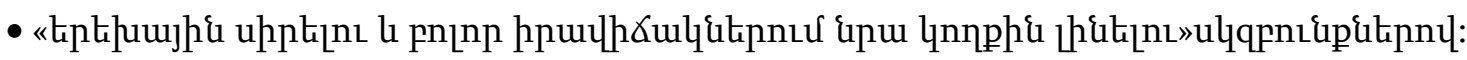




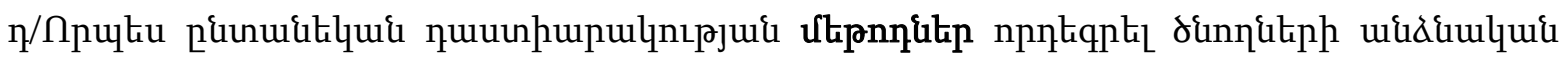

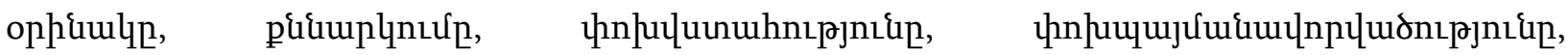

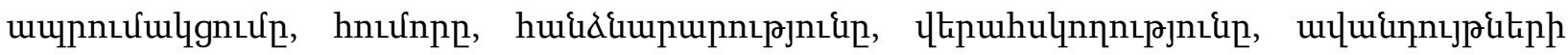

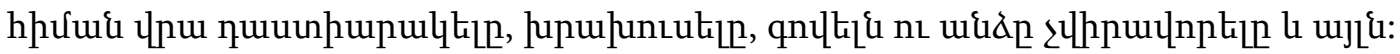

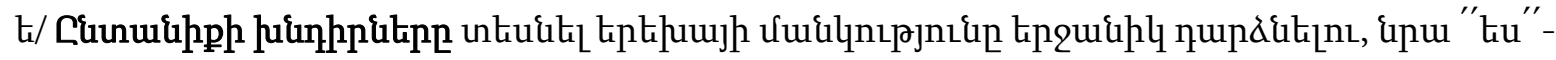

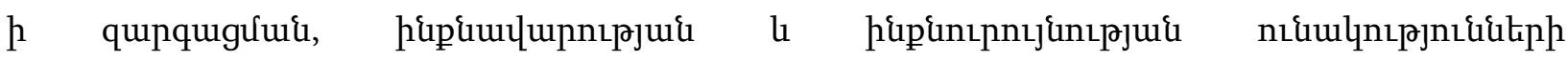

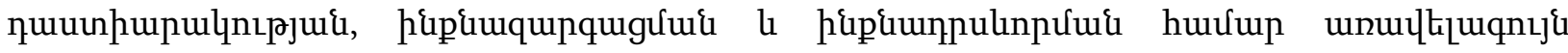

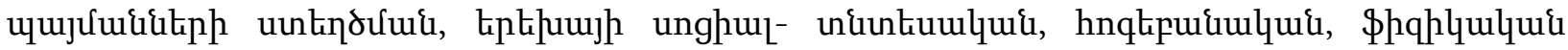

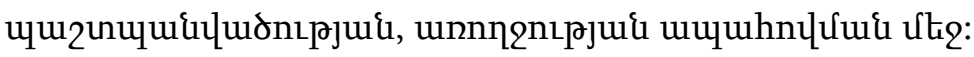

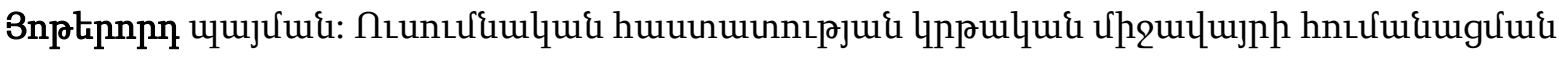

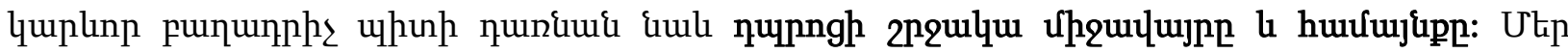

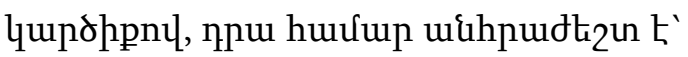

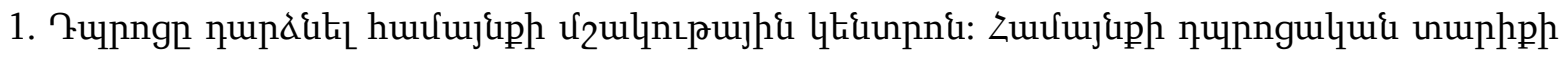

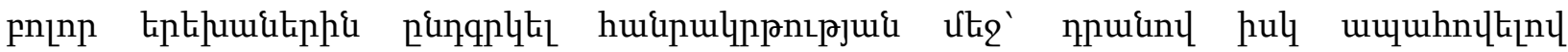

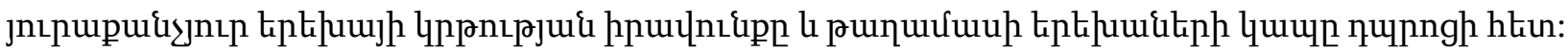

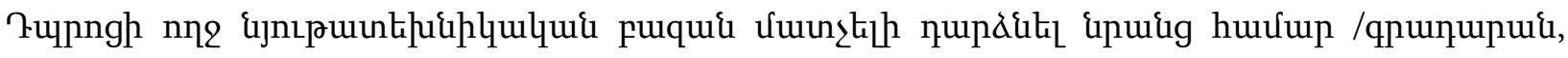

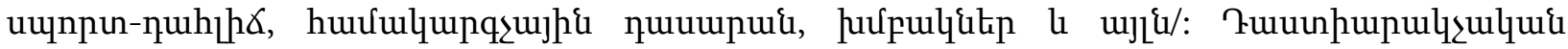

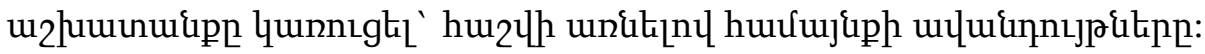

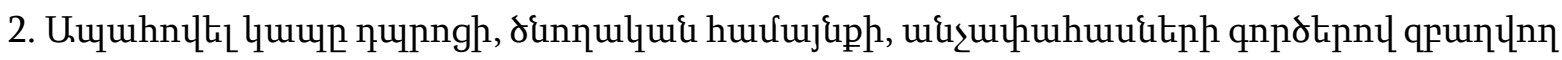

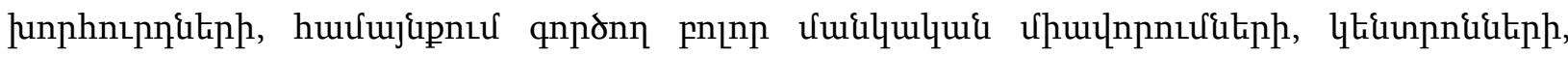

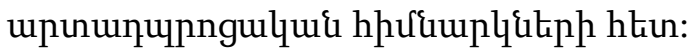

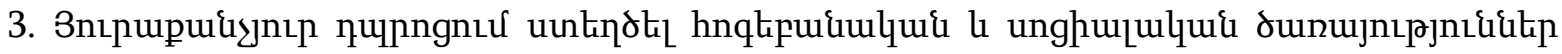

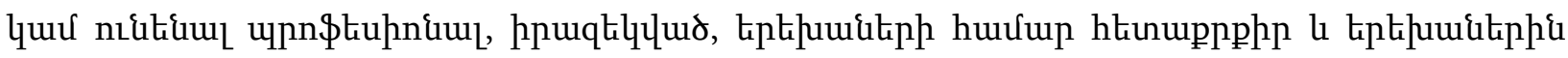

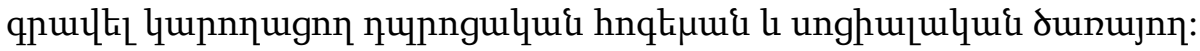

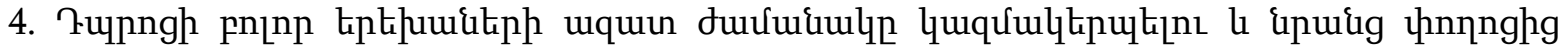

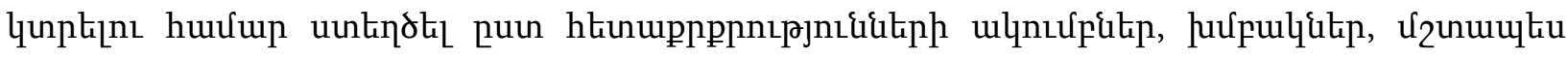

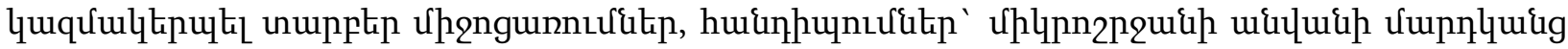

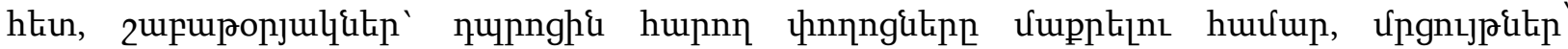

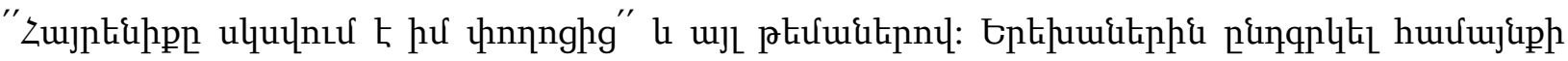

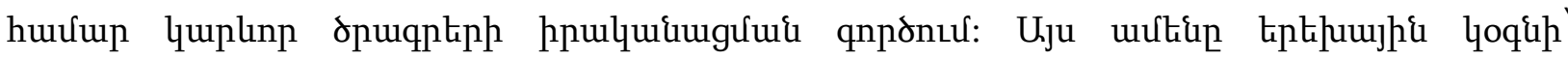

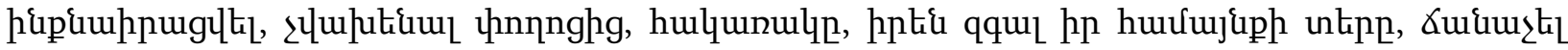

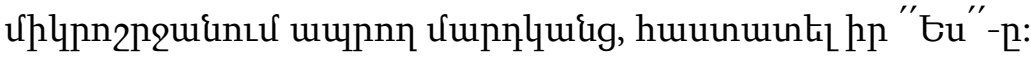

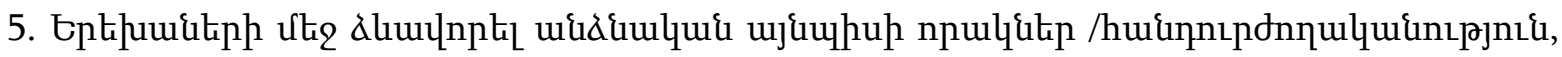




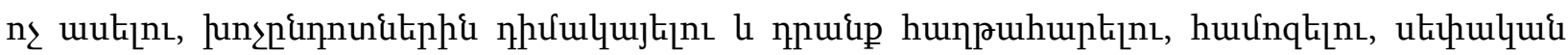

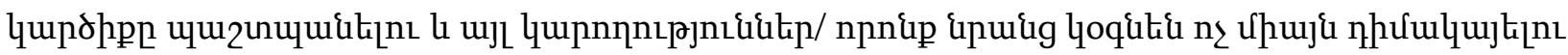

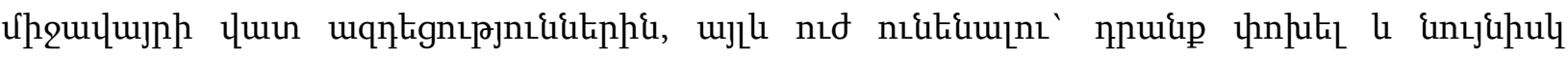
upưunuhuhl uikt:

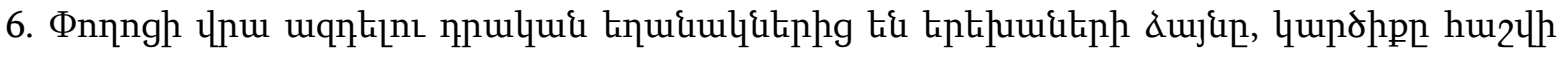

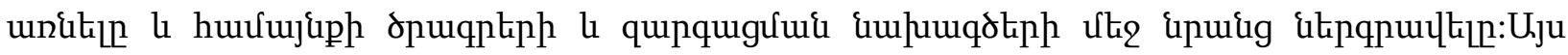

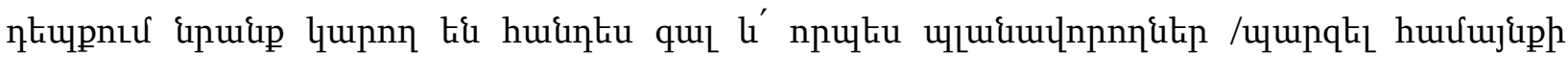

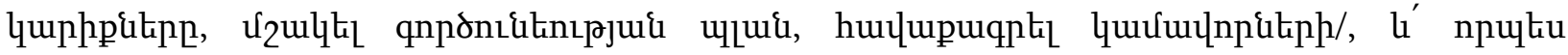

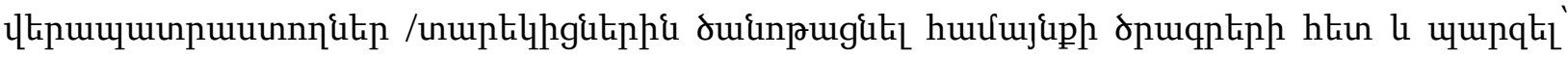

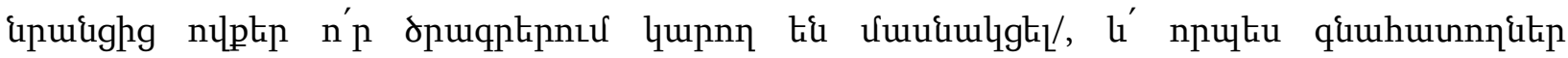

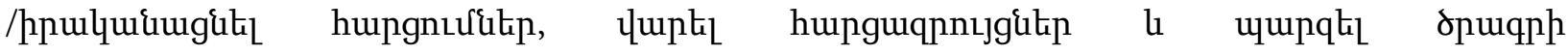

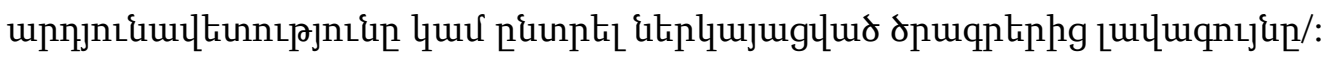

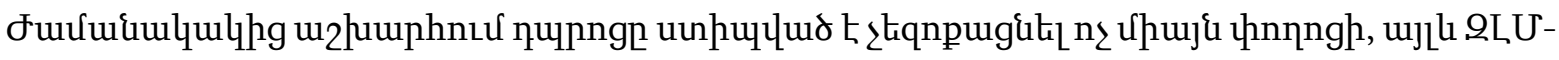

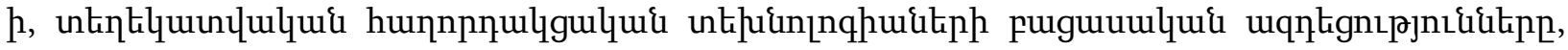

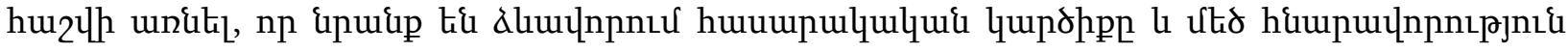

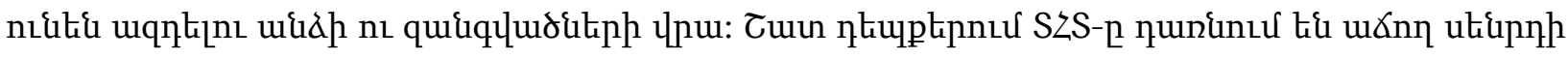

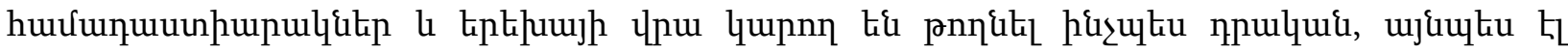

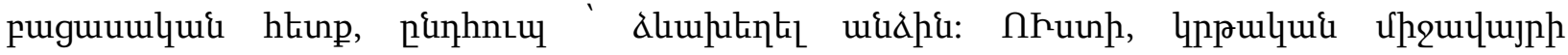

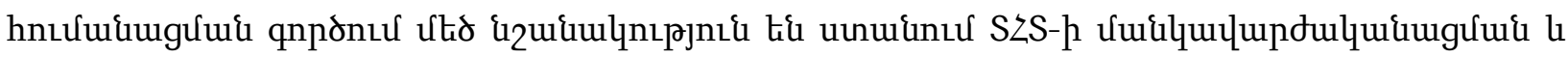

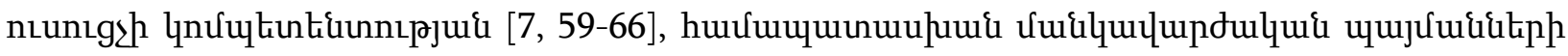

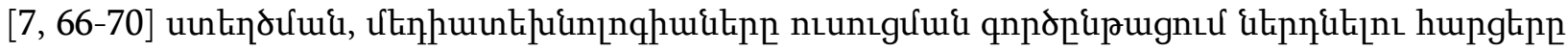

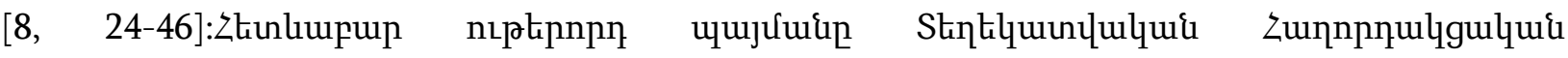

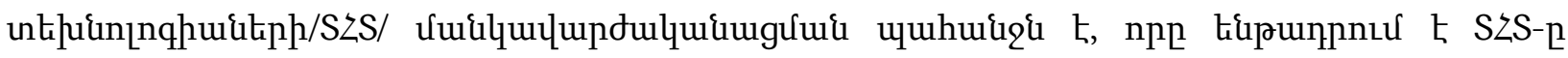

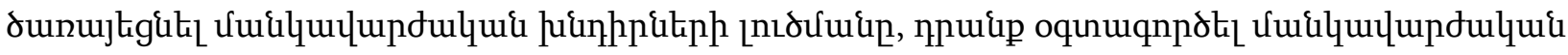

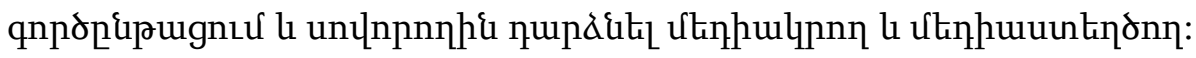

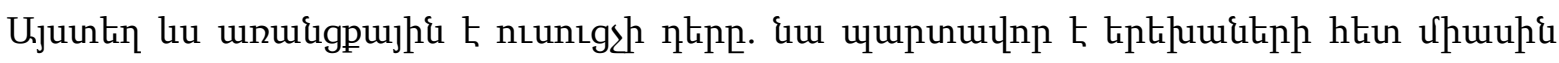

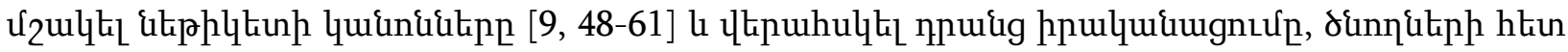

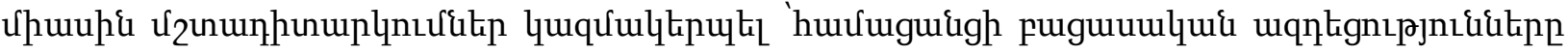

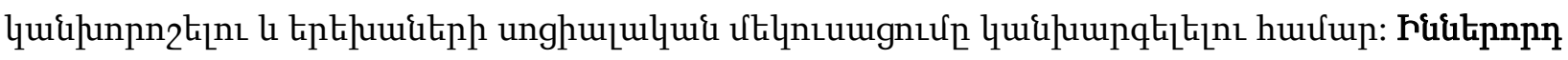

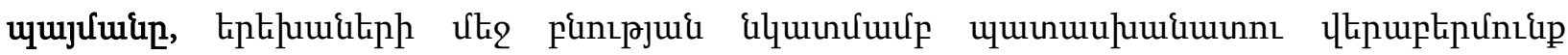

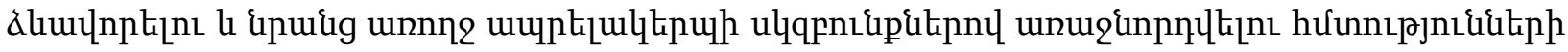

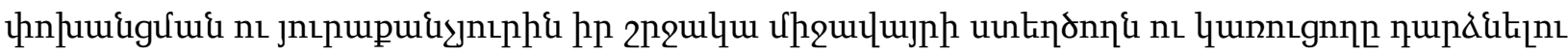
upuhuiger t: 


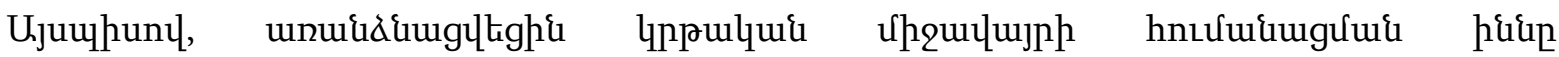

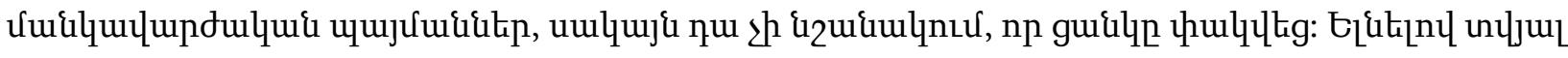

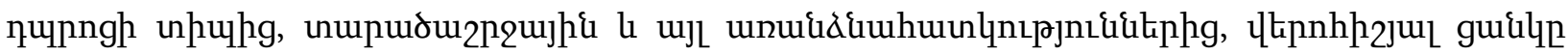

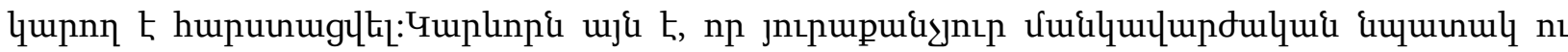

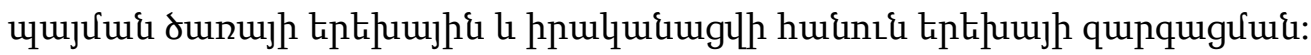

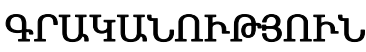

1. Декларация Конференций Организаций Обьединенных Наций по проблемам окружающей человека среды , Стокгольм 1972.

2. Джуринский А.Н. “Зарубежная педагогика” Москва, Гардарики 2008.

3. Крылова Н. Б., Александрова Е.А. Очерки понимающей педагогики, М., Народное образование 2003.

4. Практика внедрения принципов качественной педагогики ISSA, ЮНЕСКО, 2015.

5. Маркович Д.Ж.Социальная экология, М., 1991.

6. Ясвин В.А. Образовательная среда- от моделирования к проектированию, М., Смысл 2001.

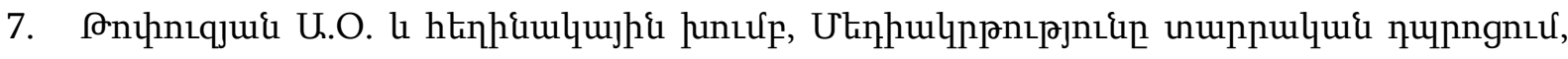
Epluwa, 2019:

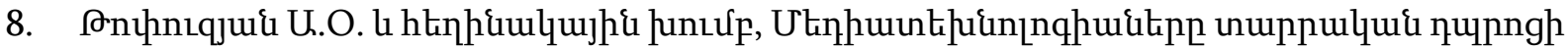

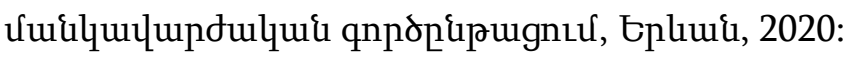

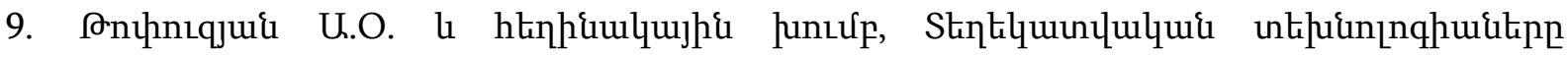

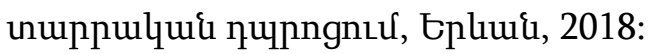

\section{PEDAGOGICAL CONDITIONS FOR THE HUMANIZATION OF THE EDUCATIONAL ENVIRONMENT}

A.O. Topuzyan's article entitled "Pedagogical conditions for the humanization of the educational environment" defines the term "humanization of the educational environment." There are given the competencies of the teacher in the humanization of the educational environment and the necessary pedagogical conditions. The role and functions of the school, family, community, ICT are highlighted, there are mentioned the complex of opportunities for the development of the person which the educational environment must provide.

Key words: pedagogical conditions, environment, influence, humanization, personality development, educational environment 